\title{
MEMOIRS
}

\section{FREDERICK JOHN CLEVERDON HONEY}

\author{
Frederick John Cleverdon Honey died on 21 November 1963 in the London \\ Hospital.
}

He was born on 28 May 1903, son of the late Herbert C. Honcy who was a Principal in the Board of Trade. He was educated at Merchant Taylors' School from 1914 to 1920, on leaving which he entered the service of the Provident Mutual Life Assurance Association. He remained there until 1928 when he was appointed to a post with the National Confederation of Employers' Organisations (now the British Employers' Confederation) where he was originally concerned with the interpretation of official statistics as these related to industrial relations and allied matters. He was appointed an Assistant Secretary of the Confederation in 1939, Secretary in 1949, and General Secretary in 1962.

He qualified as a Fellow of the Institute of Actuaries in 1935 and served as an Examiner from 1945 to 1949 . He became a Fellow of the Royal Statistical Society in 1934. He was a member of the Fellowship Club from 1948 until his death.

Honey was the author of a paper on The Estimated Population of Great Britain 19411971 , read to the Institute in 1937 and published in volume 68 of the Journal. This paper was one of a number written on population trends about this time reflecting the anxiety felt in several of the older European countries as to the long-run effect of the concurrence of a falling birth-rate and a falling death-rate at higher ages. While the forecasts contained in these papers have not been realized in the event, the discussion which they stimulated not only laid the foundations for much of the subsequent work undertaken through the Royal Commission of Population just after the war, but, by directing public attention to the social problems involved, contributed towards their solution.

A great part of his working life was spent in fields remote from those in which actuaries are normally engaged. Nevertheless he was brought closely in touch with one matter which has been exercising the minds of actuaries very much in recent years, through his membership, along with two other members of the Institute, of the Committee on the Economic and Financial Problems of the Provision for Old Age under the chairmanship of Sir Thomas Phillips. He also served on the President of the Buard of Trade's Advisory Committee on the Production Campaign appointed in 1946; the Minister of Labour's Standing Committee on the Staggering of Holidays, from 1946 to 1949; the Industrial Panel of the Civil Defence Joint Planning Staff from 1947; and the Minister of Labour's Cost of Living Advisory Committce from 1961 until his death. Apart from these formal appointments he was associated with the work of many other Government committees and of bodies with which the Confederation had links.

He was a member of the British delegation to the International Labour Conference in Geneva in June 1959 and had served since 1957 as a member of the Committee of Social Security Experts of the International Labour Office.

He acquired an extensive knowledge of the working of the agencies, both voluntary and statutory, through which wages and working conditions are settled in British industry and his advice was widely sought not merely on questions regarding the machinery of such settlement but also on substantive issues arising out of the negotiations in individual industries. He was also frequently consulted about the measures taken to promote safety and health in industry, another field in which few people in the country can have been better informed.

His manifold public services were recognized by the conferment of the honour of C.B.E. in the 1955 New Year Honours.

In his younger days he had played rugby football for the Old Merchant Taylors, and he maintained a close interest in the Old Merchant Taylors' Society, accompanying the cricket team on its annual tour on several occasions long after his playing days were over. He was for some years treasurer of St Martin's Church, West Acton. 
In manner modest and in disposition equable, he won, by his qualities of character as much as by his knowledge and judgment, the respect and confidence not only of those who like himself were concerned with representing the interests of employers but also of the senior officials of the many Government departments and trade unions with which he came into contact. His unvarying kindliness gained for him a wide circle of friends throughout industry and in the public service who will remember him with affection.

KENNETH J. BURTON

\section{SIR CHARLES FREDERICK TRUSTAM}

Charles Frederick Trustam died on 10 January 1964 after a short illness.

Born in 1900, he was educated at Hymers College, Hull, and Trinity College, Cambridge, where he graduated as a Wrangler in 1921. Duncan C. Fraser, who was then Actuary of the Royal, knew his tutor at Cambridge and recruited Trustam to the actuarial staff of his Company in I iverpool. Trustam qualified for the Fellowship of the Institute in 1925.

In 1929 he was appointed Assistant London Secretary of the Royal and began the series of rapid strides that took him to the top post in his companies and to a position of leadership in British insurance. Three years later he became Assistant London Manager and in 1936 a Sub-Manager at the Company's head office in Liverpool. Appointed a General Manager in 1944, he became the chief executive of the Royal Group in 1952 and retired on 31 December 1962 with the title of Chief General Manager.

He was President of the Chartered Insurance Institute in 1953 and Chairman of the British Insurance Association from 1957 to 1959. At New Year 1960 he received the honour of Knighthood.

As a young man, Trustam took an active part in the affairs of the Institute and his contributions usually had a mathematical flavour. For his paper in 1927 On a New Method of Calculating Model Office Reserves (J.I.A.58, 195) he received an award from the Messenger and Brown Prize Fund. He served the Institute successively as a tutor, examiner and honorary librarian. Growing responsibility in general management left him little time for professional work but he continued to serve on the administrative side of the Institute as a member of Council during the period between 1935 and 1955 and as a VicePresident from 1952 to 1954.

Trustam married in 1926 and is survived by his widow and two daughters. Outside home and business his chief interest lay in the theatre and in 1952 he joined the board of the Liverpool Playhouse, the oldest repertory theatre in the country, later becoming Chairman. He moved to London in 1960 when the Royal group of companies formed a chief administration there and continued his interest in the theatre by becoming a director of the proposed Yvonne Arnaud Memorial Theatre at Guildford. For some time he was a member of the Court of the University of Liverpool and a member of the Appointments Board of the University of Cambridge. Recently he was appointed to the three-man Location of Offices Bureau.

Trustam combined outstanding intellectual powers with a quiet and unassuming manner. He had apparently weathered the mental and physical strains of extensive travel at home and overseas and of the many exacting positions he had filled. It was therefore a shock to learn so soon after his retirement that he was afflicted with a fatal illness. His death came just over 12 months after the close of a career during which he had been a leading figure in the British insurance industry.

J. M. B E A T TIE 